\title{
Pre-hospital delay for acute coronary syndrome in China
}

Yingjuan Cao RN, Bachelor of Medicine, Fellow of Chinese Nursing Association Qilu Hospital of Shandong University, P. R. China

Doctoral Candidate

Centre for Cardiovascular and Chronic Care

Curtin University of Technology

Patricia M Davidson RN, BA, MEd, PhD

Professor of Cardiovascular and Chronic Care

Centre for Cardiovascular and Chronic Care

Curtin Health Innovation Research Institute

Curtin University of Technology

Michelle DiGiacomo BA, MHSc(Hons), PhD

Post-doctoral Research Fellow

Centre for Cardiovascular and Chronic Care

Curtin Health Innovation Research Institute

Curtin University of Technology

Min Yang RN, MSN, Fellow of Chinese Nursing Association

Professor in nursing

Masters' supervisor of Nursing School, Shandong University, P. R. China

Director of Nursing, Qilu Hospital of Shandong University, P. R. China 


\section{Abstract}

Background: Despite the effectiveness of timely reperfusion therapy for acute coronary syndrome (ACS), pre-hospital delay remains a global concern.

Aim: This paper assesses the state of the science regarding pre-hospital delay for ACS in China.

Method: Electronic databases and hand searching were undertaken using key words such as: ‘pre-hospital delay’, ‘care-seeking delay’, ‘coronary heart disease’, 'heart disease’, ‘acute coronary syndrome’, ‘unstable angina pain', ‘acute myocardial infarction', ‘cardiovascular disease’, ‘chest pain’ and 'Chin(China/Chinese)'. The Chinese search was supervised by a Chinese health librarian.

Results: Based on the search criteria, 28 studies were identified and reviewed using a standardized data extraction tool. Older age, attribution of symptoms to non-cardiac causes, lack of health insurance coverage, poor access to transportation; and female gender were identified as contributing to pre-hospital delay.

Conclusion: Health system reforms in China are necessary, particularly with regard to addressing the needs of older people, women, and other vulnerable populations in the context of the rising number of people with coronary heart disease. Developing targeted strategies, learnt from both national and international experience, are required to develop targeted interventions.

Key words: acute coronary syndrome, China, pre-hospital delay 


\section{Background}

Unlike most developed countries where death rates from coronary heart disease (CHD) have declined due to improved awareness, prevention, diagnosis and timely treatment, morbidity and mortality is expected to increase in developing countries, such as China. Such emerging economies will comprise $82 \%$ of the future global increase in CHD mortality ${ }^{[1]}$. Since the 1990s, a rapid steady increase in CHD prevalence has been observed throughout China and is a leading cause of morbidity and premature death ${ }^{[2,}$ 3]. Data from the Chinese Health Ministry showed that in 2004, CHD accounted for about $5 \%$ of total hospital bed days in large or medium-sized cities, whereas in rural country hospitals, it accounted for about $3 \%^{[4]}$. One quarter of all deaths, equating to approximately 700,000 per year, are caused by coronary events ${ }^{[5]}$. The incidence of sudden cardiac death increased significantly, to 44.6 out of 100,000 per year for men and 39.0 out of 100,000 per year for women ${ }^{[6]}$. Guo and colleagues showed that increased morbidity and mortality were associated with an increased time from symptom onset to treatment and the delay had been an important predictor of malignant clinical outcomes in patients with AMI in China ${ }^{[7]}$.

Coronary heart disease, acutely manifests as acute coronary syndrome (ACS), spanning ST-segment elevation myocardial infarction (STEMI), non-ST-segment elevation myocardial infarction (NSTEMI) and accelerated angina without evidence of myonecrosis ${ }^{[8]}$. Both international and Chinese studies have demonstrated the effectiveness of reperfusion therapy for patients with ACS ${ }^{[9-11]}$. However, early 
treatment is paramount to successful therapy. Globally, there is an inverse relationship between mortality and the time delay to reperfusion treatment with either thrombolytic therapy or percutaneous coronary intervention (PCI) ${ }^{[12-14]}$. Survival rates have been shown to improve by up to $50 \%$ if reperfusion is achieved within 1 hour of symptom onset and by $23 \%$ if achieved within 3 hours ${ }^{[15]}$. However, in the United States (US), of approximately 1.2 million people who suffer or die from an acute myocardial infarction (AMI), more than half die in an emergency department (ED) or before reaching the hospital ${ }^{[16]}$. The Global Registry of Acute Coronary Events (GRACE) study showed that only half of Australian/New Zealand patients with STEMI presented for medical care within 2 hours ${ }^{[17]}$. In patients with NSTEMI, the proportion was $41.0 \%, 38.8 \%, 29.5 \%$, and $21.2 \%$ for those from North America, Europe, Argentina and Brazil, respectively ${ }^{[17]}$.

\section{Pre-hospital delay}

In spite of the extensive research into pre-hospital delay internationally ${ }^{[18]}$, it is important to identify local factors to develop culturally appropriate interventions to decrease pre-hospital delay ${ }^{[19]}$. A study undertaken in the United Kingdom showed that the median interval from symptom onset to hospital presentation was 2.2 hours ${ }^{\text {[20] }}$. In the US, researchers found nearly half of the patients taking more than 4 hours to reach hospital ${ }^{[21]}$. In Australia, the median pre-hospital delay was 3.2 hours among patients with undifferentiated chest pain ${ }^{[22]}$. A multi-center registry from China found a median pre-hospital delay time for patients with AMI was 4 hours ${ }^{[23]}$. 
Pre-hospital delay is defined as the time from symptom onset until hospital presentation ${ }^{[24]}$. It includes two phases: (a) symptom onset to the patient's decision to seek medical attention and (b) transportation time to the hospital. The first phase consumes the major portion of delay while the second phase and in-hospital delays in receiving treatment are small and decreasing globally, including in China ${ }^{[25,26]}$. Ye et al found the delay time from symptom onset to first hospital visit in China was $3.9 \pm 1.2$ days for AMI and $11.6 \pm 4.2$ days for patients with unstable angina pain, while the delay time from hospital visit to treatment was much less, $88.7 \pm 35.8$ minutes and $30.4 \pm 12.3$ minutes, respectively ${ }^{[26]}$. In Chinese hospitals, door-to-needle/balloon time has significantly decreased, primarily due to evidence-based approach to cardiovascular care and establishing chest pain centers, ${ }^{[27,28]}$. However, to date aspects of pre-hospital delay in China have not been as well studied.

\section{Method}

The electronic databases Medline, ScienceDirect, PsycInfo, CBMdisc, CNKI, the Internet, using the Google Scholar search engine, were interrogated using the search terms 'pre-hospital delay’, 'care-seeking delay’, 'coronary heart disease’, 'heart disease', ‘acute coronary syndrome’, ‘unstable angina pain’, ‘acute myocardial infarction', ‘cardiovascular disease’, ‘chest pain’, ‘Chin(China/Chinese)'. A Chinese-speaking librarian reviewed the search strategy. Hand searching of 
reference lists and Chinese cardiac journals were also undertaken. The conclusions of each of these studies were synthesized using the method of an integrative review ${ }^{[29]}$. The integrative review method is a useful strategy for collating and interpreting a body of literature to draw conclusions and make recommendations for practice, policy and research. A key focus of data extraction was the identification of pre-hospital delay time and the generation of independent predictors of delay and description of local factors. Thematic analysis of key themes was undertaken and issues generated from the review were compared and contrasted to the international literature.

\section{Findings}

Thirty-two data-based research articles were identified. Articles both in Chinese and English were reviewed. In order to obtain a broad perspective of issues, no studies were excluded on the basis of methodological rigor or design. Twenty eight studies were identified as shown in Table 1. In parallel with international studies, older age, atypical symptoms, and decreased access to emergency medical systems impacted adversely on health outcomes. The findings of these studies are considered within the

context of the articles retrieved for this review and the international literature ${ }^{[30]}$. Specifically, implications for the Chinese health care system are identified.

Age

In Table 1, 16 of 28 studies show that older age contributed to pre-hospital delay. In 
the US, Goff and colleagues found delay was increased by 14 minutes for every 10-year age increment ${ }^{[31]}$. Dracup and colleagues found that older individuals had lower knowledge scores regarding the symptoms of ACS and the appropriate course of action to take, as well as the level of perceived risk for future cardiac events ${ }^{[32]}$. Similar findings from Chinese studies showed that older individuals were less responsive to symptoms due to the increased frequency of atypical symptoms ${ }^{\text {[3] }}$. Atypical ACS symptoms can also contribute to prolonged pre-hospital delay ${ }^{[26,34,35]}$. Wang et al found that only 20-40\% of older ACS patients experienced typical onset symptoms ${ }^{[36]}$. For older people in China, transportation is another problematic issue, particularly for those who have symptoms at night. Individuals worry about bothering family members and delay seeking treatment, concerns also demonstrated in international studies ${ }^{[30]}$. On the other hand, family members' awareness regarding cardiac events impacts on accessing treatment ${ }^{[33,37]}$. In China, if current aging trends continue, by 2040, those aged 65 years and above will have increased to almost one fifth of the population ${ }^{[38]}$. The aging of the population is a major driving force and is predicted to produce a $200 \%$ increase in deaths from cardiovascular disease between the years 2000 and $204{ }^{[38]}$. Therefore, addressing the knowledge, attitudes and beliefs of older people is important.

\section{Attribution of symptoms to cardiac causes}

Individuals who correctly interpreted their ACS symptoms have been found to seek treatment faster than those who do not ${ }^{[24,37,39,40]}$. Li and colleagues found it took 3.6 
times less for those who attributed symptoms to cardiac events to seek medical treatment than those who did not ${ }^{[37]}$. The lack of recognition of ACS symptoms and the low perception of the associated risks can contribute to prolonged delay ${ }^{[41]}$. This is in accordance with a US study that showed a person's belief that they would never have an AMI significantly increased the odds of delay compared with others ${ }^{[42]}$. The study by Zhang et al illustrated the knowledge level of heart attack symptoms among Beijing residents was comparable or lower than those described in Western regions more than a decade ago ${ }^{[43]}$.

Internationally, Dracup and colleagues found that even following diagnosis of ACS and numerous interactions with health care professionals, individuals' knowledge of ACS symptoms remained poor ${ }^{[32]}$. Fourteen of the 28 studies in this review (Table 1) identify that diabetes or heart disease history was a factor impacting on pre-hospital delay. A prior history of heart disease and diabetes did not motivate patients to seek prompt medical care for suspected ACS symptoms in a Beijing study ${ }^{[44]}$. Similarly, individuals who had undergone coronary artery bypass graft (CABG) surgery felt less at risk for a future AMI than other individuals of the same age ${ }^{[32]}$. In diabetic patients, the absence of traditional symptoms delayed treatment seeking ${ }^{[19]}$.

\section{Lack of health insurance}

Socioeconomic status is an important factor impacting on decisions to seek medical care promptly ${ }^{[45]}$. The high cost of hospitalization deters people from seeking medical 
assistance immediately ${ }^{[46-48]}$. Health insurance coverage is a direct and modifiable predictor of delay in seeking treatment due to the current fee-for-service medical model in China. Seven of the 28 studies in Table 1 demonstrate that health insurance coverage was a significant factor leading to pre-hospital delay in patients with suspected ACS. The lower the level of health insurance coverage, the longer the delayed time observed ${ }^{[32,44]}$. As most Chinese patients self-fund their own medical treatment and do not have health insurance, there is a positive relationship between CHD and economic burden. A Chinese study undertaken by Wu et al depicted that patients with monthly family income less than 1000 Yuan (approximately \$145) tended to delay seeking medical care (US\$: $Y R M B=1: 6.8)^{[49]}$. Consequently, there is less access to treatment and as a consequence inferior outcomes in CHD within the Chinese population ${ }^{[50,51]}$.

\section{Transportation}

Presenting to hospital other than via ambulance is another factor associated with pre-hospital delay for ACS both in China and internationally ${ }^{[44,52]}$. Seven studies in this review concluded that transportation is a major barrier for patients seeking prompt medical treatment. Delay time was demonstrated to be less among individuals who used an emergency medical system (ambulance) than those who used other means ${ }^{[32,49]}$. Wu et al found that less than half the population surveyed knew about the ambulance system and less than $10 \%$ reached hospital via ambulance in Tianjin city in $1997^{[46]}$. Nearly a decade later, in 2006, Zhang et al ${ }^{[43]}$ showed that in Beijing, 
a neighboring city, only $31.7 \%$ of participants reported calling an ambulance if they suspected they were experiencing a heart attack. The lack of access to transportation is an important consideration in individuals not pursuing help upon symptom onset at night, particularly, older people and those living in rural areas ${ }^{[19,44,47]}$.

\section{Female gender}

Women have been found to delay significantly longer than men in seeking treatment by international and Chinese researchers ${ }^{[21,53-56]}$. Studies have shown that there are longer delay times in women leading to inferior outcomes ${ }^{[57,58]}$. Six studies in this review illustrated female gender is a factor contributing to prolonged delay in seeking medical attention in the course of ACS symptoms. However, being female as an independent factor related to pre-hospital delay for ACS is controversial ${ }^{[46,59]}$. Gao and colleagues found that female gender was not an independent factor relating to prolonged delay, although it occurred more often in women potentially due to other factors such as older age and diabetic history ${ }^{[60]}$.

Factors such as acuity and severity of ACS symptoms were associated with prompt hospital admission ${ }^{[37,46,61]}$. Sudden onset and more progressive symptoms were associated with less time delayed for seeking medical service ${ }^{[46,61]}$. Not wanting to trouble others and waiting for symptoms to dissipate impeded patients seeking help, especially at night ${ }^{[62]}$. A qualitative study using in-depth interviews described that some people perceived health as very private and were reluctant to call an ambulance 
or let others know ${ }^{[45]}$. Also, socioeconomic status indicators including education and income were barriers for timely treatment-seeking for ACS ${ }^{[32,36]}$. Those with higher education and income levels recognized the importance of seeking timely treatment [32, 46, 63]. Internationally, race is an independent factor of pre-hospital delay for ACS [31]. We were unable to identify data reporting similar trends in the minority groups in China.

Some studies identified in this review also attributed pre-hospital delay for ACS to community hospitals which provide neither thrombolytic nor PCI reperfusion therapy ${ }^{[47,64]}$. Delay times were long and increased mortality because patients missed the optimal treatment time window for revascularization.

\section{Implications for the Chinese health care system}

Coronary revascularization, including thrombolytic therapy and primary PCI as early as possible after onset of ACS is an important factor influencing health outcomes. Raising awareness through heart health education initiatives and health care system reform are necessary strategies to improve outcomes.

\section{Raising heart health awareness}

There is a general lack of knowledge regarding ACS among the Chinese population, potentially related to insufficient health campaigns ${ }^{[65]}$. Cardiovascular disease is a new health care consideration in China, where the primary focus has not yet shifted 
from infectious disease to chronic disease ${ }^{[66]}$. The findings in this study demonstrate the urgent need for reinforcing health education to raise awareness of high prevalence of heart disease, the nature of typical and atypical ACS symptoms, benefits of early treatment, and assessing and modifying risk factors. Yet, within the context of the international experience, education alone is unlikely to achieve significant improvements in pre-hospital delay ${ }^{[67]}$. Initiatives should particularly target at vulnerable populations such as older people, women, and individuals and families in rural areas and those from lower socio-economic background and poor health literacy.

The period of hospitalization following acute hospitalization is a critical time for patients to focus on their own health and receive updated health information. Hospital-run health education clinics may assist in helping patients with selfmanagement strategies and action plans for cardiac events. Health professionals need to be vigilant concerning vulnerable populations and provide individualized education plans. Initiatives such as the Go Red for Women campaign aim to improve women's awareness of heart disease in the US, Australia and other countries ${ }^{[68]}$ and would be a useful model in China to shift public attention to the heart health of women and decrease their pre-hospital delay. Social marketing campaigns and health promotion initiatives, such as healthy eating and smoking cessation, are also necessary to decrease the burden of CHD.

Health care system reform 
The expense of hospitalization limits individuals from seeking immediate treatment. Expanding health insurance coverage should be a priority of the ongoing health reform ${ }^{[69]}$. Equitable access to medical care and economic support for vulnerable patients such as older people, women, and low socio-economic groups would be potentially an effective means of decreasing pre-hospital delay and poor outcomes of patients with ACS in China.

It appears that the decision to call for an ambulance represents an important health seeking behavior that results in shorter delay. Furthermore, ECGs done en route to hospital often expedites treatment as compared to those initiated after hospital arrival ${ }^{[46]}$. However, this review identified that only a small portion of patients were aware of the emergency system and few arrived via ambulance. Even in the capital city, Beijing, less than one third of the respondents reported that they would call themselves an ambulance for suspected heart attack ${ }^{[43]}$. This may explain the study results which showed less than $30 \%$ of AMI patients arrived at hospital via ambulance $^{[33,49]}$. Improving accessibility to emergency transportation will likely improve outcomes. The large population and vast territory in China mean that establishing effective emergency systems is vital. Educating the public to call an ambulance will strengthen the perception that 'every minute counts to save lives'. Implementing pre-hospital thrombolytic treatment has been successful in some hospitals and needs further development in China ${ }^{[70]}$. 
Finally, training professionals in community clinics or hospitals to initiate reperfusion therapy is important. This may reduce the delay time for ACS patients who first seek medical attention in these settings. Also, developing networks between advanced hospitals and community health services, establishing ACS clinical pathways and increasing access to chest pain centers are important strategies to improve health outcomes ${ }^{[65]}$.

\section{Conclusion}

This review has determined that pre-hospital delay for ACS in China is a significant health care issue. Given the burden of this problem in China, the numbers of studies and participants is sparse. Fortunately, there is an expansive international experience that can assist in formulating responses to this challenge. Implementing evidence based strategies and developing strategies tailored to Chinese people and the Chinese health system is vital to improve health outcomes. Future research should focus on understanding Chinese people's awareness, and attitudes towards ACS in order to develop and implement culturally appropriate interventions.

\section{Clinical Pearls}

- Pre-hospital delay for acute coronary syndromes is a global concern

- The increasing burden of coronary heart disease in China requires a focus on improving systems of care and increasing the awareness of early access to treatment

- Addressing the needs of older people, those with lower levels of education and other vulnerable populations in China should be considered in developing interventions. 


\section{Reference list}

[1]. World Health Organization (2008) Deaths from coronary heart disease, http://www.who.int/cardiovascular_diseases/en/cvd_atlas_14_deathHD.pdf. Accessed November 28, 2009. Center for Research and Control of Cardiovascular Diseases, 2005 Report on cardiovascular diseases in China. Beijing: Encyclopedia of China Publishing House. 2005. Zhang XH, Lu ZL, Liu L. Coronary heart disease in China. Heart. 2008; 94:1126-1131. The Ministry of Health., China health statistics year book. Beijing: Publishing House of Peking Union Medical College. 2005. He J, Gu DF, Wu XG, et al. Major causes of death among men and women in China. $N$ Engl J Med . 2005;353(11):1124-1134. Hua W, Liu XQ, Zhao LC, Mai JZ. Incidence of sudden cardiac death in China, analysis of 4 regional populations. JACC. 2009; 54(12):1110 - 1118. Guo LF, Peng YG, Li QX, He JH, Zhao D, Hong ZG. Prehospital delay time and mortality in patients with acute myocardial infarction. Zhonghua Xin Xue Guan Bing Za Zhi. 2007; 35(1):40-43.

Chew DPB, Allan RM, Aroney CN, Sheerin NJ. National data elements for the clinical management of acute coronary syndromes. Med J Aust. 2005; 182 (9 Suppl): S1-S16. Chinese Society of Cardiology, S.O.I.C., A data analysis of the third national coronary intervention registry. Chinese J Cardiol. 2002; 30:719-723. 
main coronary artery stenting in Chinese. Chinese J Cardiol. 2005; 33:210-215.

[11]. Aroney CN, Aylward P, Kelly AM, Chew DPB, Clune E. National Heart Foundation of Australia Cardiac Society of Australia and New Zealand Guidelines for the management of acute coronary syndromes 2006. Med J Aust. 2006; 184(8):S1-S30

[12]. Zijlstra F, Patel A, Jones M, et al. Clinical characteristics and outcome of patients with early $(<2 \mathrm{~h})$, intermediate $(2-4 \mathrm{~h})$ and late $(>4 \mathrm{~h})$ presentation treated by primary coronary angioplasty or thrombolytic therapy for acute myocardial infarction. Eur Heart J. 2002; 23:550-557.

[13]. De Luca G, Suryapranata H, Ottervanger JP, Antman EM. Time delay to treatment and mortality in primary angioplasty for acute myocardial infarction: every minute of delay counts. Circulation. 2004; 109(10): 1223-5.

[14]. Ren H, Zhong Y. Therapeutic assessment between the thrombolysis in 6 hours and delayed thrombolsis after onset of acute myocardial infarction. Zhongguo Wei Zhong Bing Ji Jiu Yi Xue. 2004; 16(3):155-157.

[15]. Simoons ML, Serruys PW, Brand MVD, et al. Early thrombolysis in acute myocardial infarction: limitation of infarct size and improved survival.. J Am Coll Cardiol. 1986; 7(4):717-728.

[16]. American Heart Association. Heart Disease and Stroke Statistics Year 2005 Update. Dallas, Tex: American Heart Association. 2005.

[17]. GRACE study. Prehospital delay in patients with acute coronary syndromes (from the Global Registry of Acute Coronary Events [GRACE]). Am J Cardiol. 2009; 103:598-603.

[18]. Dracup K, Moser DK, Eisenberg M, Meischke H, Alonzo AA, Braslow A. Causes of delay in 
seeking treatment for heart attack symptoms. Soc Sci Med. 1995; 40(3): 379-392

[19]. Zhao MZ, Hu DY, Xu YY. Analysis of factors associated with delay time of treatment in patients with acute myocardial infarction. Chin J Gen Pract. 2002; 1(2): 81-84.

[20]. Horne R, James D, Petrie K, Weinman J, Vincent R. Patients' interpretation of symptoms as a cause of delay in reaching hospital during acute myocardial infarction. Heart.2000; 83(4):388-393.

[21]. McGinn AP, Rosamond WD, Goff JDC, Taylor HA, Miles JS, Chambless L. Trends in prehospital delay time and use of emergency medical services for acute myocardial infarction: Experience in 4 US communities from 1987-2000. Am Heart J. 2005; 150(3):392-400.

[22]. Taylor DM, Garewal D, Carter M, Bailey M, Aggarwal A. Factors that impact upon the time to hospital presentation following the onset of chest pain. Emerg Med Australas. 2005; 17(3):204-211.

[23]. Yu LT, Zhu J, Mister R, et al. The Chinese registry on reperfusion strategies and outcomes in ST-elevation myocardial infarction. Chin J Mult Organ Dis Elderly. 2006; 34:593-597. Ottesen MM, Dixen U, Christian TP, Lars K. Prehospital delay in acute coronary syndrome--an analysis of the components of delay. Int J Cardiol. 2004; 96(1):97-103. evaluation of the acute coronary syndrome (ACS) response index. Res Nurs Health. 2007; 30(6):584-594.

[26]. Ye SL, Wang ZM, Xie CL, Chen YL. Analysis and strategy of related causes for delayed treatment in acute coronary syndrome. Guangzhou Yi Xue Yuan Xue Bao. 2005; 33(4):30-31. 
infarction in modern China. CVD Prevention and Control. 2009; 4(1):9-18.

[28]. Hu DY, Zhao MZ. Early recognition and treatment for patients with chest pain. Chin J Gen Pract. 2003; 2(2):75-76.

[29]. Whittemore R, Knafl K. The integrative review: updated methodology. J Adv Nurs. 2005; 52(5):546-553.

[30]. Moser DK, Kimble LP, Alberts MJ, Alonzo A, et al. Reducing Delay in Seeking Treatment by Patients With Acute Coronary Syndrome and Stroke: A Scientific Statement From the American Heart Association Council on Cardiovascular Nursing and Stroke Council. Circulation. 2006; 114:168-182.

[31]. Goff DC Jr, Feldman HA, McGovern PG, et al. Prehospital delay in patients hospitalized with heart attack symptoms in the United States: The REACT trial. Am Heart J. 1999; 138(6):1046-1057.

[32]. Dracup K, McKinley S, Doering LV, et al. Acute coronary syndrome: what do patients know? Arch Intern Med. 2008; 168(10):1049-1054.

[33]. Wang BF, Han XF, Wang J. Analysis of factors associated with prehospital delay among AMI patients. Zhongguo Yi Shi Jin Xiu Za Zhi. 2007; 30(12A):50-51.

[34]. Wang LZ, Li YJ. Investigation factors of prehospital delay in AMI patients. Zhongguo Kang Fu Yi Xue Za Zhi. 2003; 18(9):51-52.

[35]. He GX, Zhang H, Chen Y. Analysis on the factors affecting prehospital delay in elderly patients with acute myocardial infarction. Zhongguo Lao Nian Xue Za Zhi. 2005;(8):965.

[36]. Wang SW, Qian CY. Geriatric cardiology 1998, P438. Beijing: People’s Medical Publishing House. 
[37]. Li QH, Li L, Tie YR. Analysis of factors influencing prehospital delay in CHD patients with AMI. Zhongguo Wu Zhen Xue Za Zhi. 2008; 18(14):3524-3525. Cardiovascular Disease in Developing Economies. NY: Columbia University: New York. 2004. Li L, Wang YZ, Zhang HJ. Pre-hospital delay state to see doctor of acute myocardial infarction patients and its influencing factors. Hu Li Yan Jiu. 2007; 1(3A):611-614. Wang HP, Zhang C, Liu QH. Investigation on factors influencing prehospital delay among AMI patients. Zhongguo Wu Zhen Xue Za Zhi. 2007; 7(27):6705-6706. Li SL, Yue SM. Analysis of factors of treatment delay and strategy in patients with AMI. Zhongguo Mei Tan Gong Ye Yi Xue Za Zhi. 2006; 9(7):735. among lower income, urban women. Heart Lung. 2007; 36(2): 96-104. Zhang QT, Hu DY, Yang JG, Zhang SY, Zhang XQ, Liu SS. Public knowledge of heart attack symptoms in Beijing residents. Chin Med J. 2007;120(18):1587. delayed time before treatment in patients with acute myocardial infarction. Beijing Yi Xue. 2008; 30(1):20-22.

[45]. Li L, Wang YZ, Zhang HJ. Probe into causes of delay to see doctors for acute myocardial infarction patients with qualitative research. Hu Li Yan Jiu. 2005; 19(7A):1212-1214. treatment for patients with acute myocardial infarction. Zhongguo Wei Zhong Bing Ji Jiu Yi Хие. 1998; 10(1):55-56. 
[47]. He GX, Chen YP, Tang XH. An analysis of related causes for delayed treatment in elderly acute myocardial infarction and strategies. Hu Li Xue Za Zhi. 2004. 19(11):3-5.

[48]. Qin J. Analysis of factors relating to delay treatment in patients with acute myocardial infarction. Yi Yao Chan Ye Zi Xun. 2005; 2(24):143.

[49]. Wu Y, Zhang Y, Li YQ, Hong BL, Huang CX. Factors associated with the extent of care-seeking delay for patients with acute myocardial infarction in Beijing. Chin Med J. 2004; 117(12):1772-1777.

[50]. Yang L, W M, C B, Xu J. Economic burden of cardiovascular diseases in China. Expert Rev Pharmacoecon Outcomes Res. 2008. 8(4):349-356.

[51]. Tang JL, Hu YH. Drugs for preventing cardiovascular disease in China. BMJ.2005; 330(7492):610-611.

[52]. Xing YH, Fu ZH, Yang XQ. A survey of influencing factors on prehospital transferring delaying time in patients with acute myocardial infarction. $\mathrm{Hu}$ Li Yan Jiu. 2005; 19(4B):675-677.

[53]. Gibler WB, Armstrong PW, Ohman EM, et al. Persistence of delays in presentation and treatment for patients with acute myocardial infarction: the GUSTO-I and GUSTO-III experience. Ann Emerg Med. 2002; 39(2):123-130.

[54]. Xu WQ, Ma XF, Dai LL. Factors associated with delay in hospitalization for acute myocardial infarction. Qilu Yi Xue Za Zhi. 2003; 18(3):285-288.

[55]. Ding SQ, Tao XL, Xiao ML. Prehospital delay in patients with Acute Myocardial Infarction and Its nursing Implications. Hu Li Xue Za Zhi. 2008; 23(3):23-24.

[56]. Zhang H, Zheng HW, Wang P, Zou HY, Liang YL. Investigation influencing factors of 
treatment delay in patients with acute coronary syndrome. Nurs J Chin PLA. 2008; 25(2A):17-19.

[57]. Jiang SL, Ji XP, Zhao YX, et al. Predictors of in-hospital mortality difference between male and female patients with acute myocardial infarction. Am J Cardiol. 2006;98(8):1000-1003.

[58]. Mikhail G. Coronary heart disease in women: is underdiagnosed, undertreated, and under-researched. BMJ. 2005; 331(7515): 467-468.

[59]. Liu HM, Zhou XR, Luo L. Analysis on factors delayed to receive medical treatment in patient s with myocardial infarction. Hu Li Yan Jiu. 2006; 20(11A):2872-2873.

[60]. Gao YS, Qian XX, Ma DB. Factors Associated with prehospital delay time in patients with acute myocardial infarction. Zhongguo Xun Huan Za Zhi. 2001; 16(4):272-274.

[61]. Guo JC, Hua Q, Xu M, Wen YM, Liu DX, L DB. Time distribution and relative factors of prehospital delay in the patients with acute ST-segment elevation myocardial infarction. Zhongguo Wei Zhong Bing Ji Jiu Yi Xue. 2007; 27(3):263-266.

[62]. Guo JC, Hua Q, Liu DX, et al. Analysis of factors related to prehospital delay for acute ST elevation myocardial infarction. Chin J Gen Pract. 2006; 5(2):114-116.

[63]. Shi JP, Wang BS, Wang TJ, et al. Analysis of multi-factors related to delayed treatment in patients with acute coronary event. Zhongguo Gong Gong Wei Sheng. 1995; 15(1):41-42.

[64]. Hu DY, Xu ZM, Cui L, et al. Analysis of time distribution and causes in thrombolysis of acute myocardial infarction. Ji Zhen Yi Xue. 1996; 5(4):195-203.

[65]. Hu DY. Update the concept, converse the mode---to meet the challenge of the epidemic of cardiovascular disease. Natl Med J China. 2005; 85(126):1803-1804. 
China. Lancet. 2008; 372(9650):1697-1705.

[67]. Kainth A, Hewitt A, Sowden A, et al. Systematic review of interventions to reduce delay in patients with suspected heart attack. Emerg Med J. 2004; 21(4):506-508.

[68]. World Heart Federation. Go Red for Women. WWW.world-heart-federation.org, Accessed November 7, 2009.

[69]. Liu YL, Rao KQ, Wu J, Gakidou Emmanuela. China's health system performance. Lancet. 2008;372(9653): 1914-1923.

[70]. Shen S. Implementing pre-hospital and in-hospital thrombolytic treatment for acute myocardial infarction using 120-CCU mode. Zhongguo Wu Zhen Xue Za Zhi. .2004; 14(12):2052-2053.

[71]. Gong JJ, Wang PB, Wang JB, Shan RQ, Teng CQ. Factors associated with prehospital delay time in patients with acute myocardial infarction. Lin Chuang Hui Cui. 2004; 19(15):855-857.

[72]. Li N, Zhang SR, Zhang YP. Coping mode of patient s with acute coronary syndrome and its influencing factors. Chin Nurs Res. 2004; 18(115):383-385.

[73]. Cheng SJ, Guo LF, Liu JY, Zhu XL, Yan HB.Factors influencing prehospital delay for patients with acute myocardial infarction. JGC. 2007; 4(1):11-13. 
Table 1: Summary of studies on pre-hospital delay for acute coronary syndrome in China

\begin{tabular}{|c|c|c|c|c|c|c|}
\hline Authors & Study source & \begin{tabular}{|l|} 
Data \\
source
\end{tabular} & Place & $\mathbf{N}$ & $\begin{array}{l}\text { Pre-hospital Delay Time } \\
\text { (PDT) }\end{array}$ & Conclusions \\
\hline $\begin{array}{l}\text { Mingzhong } \\
\text { Zhao, } \\
\text { Dayi Hu, } \\
\text { Yuyun Xu. } \\
\text { [19] }\end{array}$ & $\begin{array}{l}\text { Chinese Journal } \\
\text { of General } \\
\text { Practitioners (in } \\
\text { Chinese) }\end{array}$ & $\begin{array}{l}\text { Medical } \\
\text { record and } \\
\text { patient } \\
\text { interview }\end{array}$ & Beijing & $\begin{array}{l}\mathrm{N}=184 \\
(\mathrm{M} 112, \mathrm{~F} 72)\end{array}$ & $\begin{array}{l}\text { PDT } \leq 6 h r s, n=119 \\
\text { PDT }>6 h r s, n=65\end{array}$ & $\begin{array}{l}\text { - Older age, diabetes history, } \\
\text { atypical angina and onset at } \\
\text { night were independent factors } \\
\text { associated with prolonged delay } \\
\text { for AMI. }\end{array}$ \\
\hline $\begin{array}{l}\text { Baofu Wang, } \\
\text { Xiaofeng } \\
\text { Han, } \\
\text { Jian Wang. } \\
\text { [33] }\end{array}$ & $\begin{array}{l}\text { Chinese Journal } \\
\text { of } \\
\text { Postgraduates } \\
\text { of Medicine (in } \\
\text { Chinese) }\end{array}$ & $\begin{array}{l}\text { Patient } \\
\text { interview }\end{array}$ & Beijing & $\begin{array}{l}\mathrm{N}=412 \\
(\mathrm{M} 291, \mathrm{~F} 121)\end{array}$ & $\begin{array}{l}\text { PDT } \leq 2 h r s, n=101 \\
\text { PDT }>2 h r s, n=311\end{array}$ & $\begin{array}{l}\text { - Older age, diabetic history and } \\
\text { onset at night were independant } \\
\text { factors related to prehospital } \\
\text { delay for AMI patients. Hospital } \\
\text { arrival via ambulance } \\
\text { significantly reduced PDT for } \\
\text { suspected AMI patients. }\end{array}$ \\
\hline $\begin{array}{l}\text { Shaoling Ye, } \\
\text { Zhiming } \\
\text { Wang, } \\
\text { Chenli Xie, } \\
\text { Yulan Chen. } \\
\text { [26] }\end{array}$ & $\begin{array}{l}\text { Academic } \\
\text { Journal of } \\
\text { Guangzhou } \\
\text { Medical } \\
\text { College (in } \\
\text { Chinese) }\end{array}$ & $\begin{array}{l}\text { Medical } \\
\text { record \& } \\
\text { patient } \\
\text { interview } \\
\text { via } \\
\text { telephone }\end{array}$ & $\begin{array}{l}\text { Guangd } \\
\text { ong } \\
\text { (souther } \\
\text { n China) }\end{array}$ & $\begin{array}{l}\mathrm{N}=130 \\
(\mathrm{M} 87, \mathrm{~F} 43)\end{array}$ & $\begin{array}{l}\text { PDT } \leq 12 \mathrm{hrs}, \mathrm{n}=43 \\
\text { PDT }>12 \mathrm{hrs}, \mathrm{n}=87 \text {. }\end{array}$ & $\begin{array}{l}\text { - Atypical symptom contributed to } \\
50.8 \% \text { delay and medical } \\
\text { expense and transportation } \\
\text { accounted for } 16.9 \% \text { delay for } \\
\text { ACS patients. }\end{array}$ \\
\hline $\begin{array}{l}\text { Lizi Wang, } \\
\text { Yajie Li. }^{\text {[34] }}\end{array}$ & $\begin{array}{l}\text { Chinese Journal } \\
\text { of } \\
\text { Rehabilitation } \\
\text { Medicine(in }\end{array}$ & $\begin{array}{l}\text { Patient } \\
\text { interview }\end{array}$ & $\begin{array}{l}\text { Guangd } \\
\text { ong } \\
\text { (souther } \\
\text { n China) }\end{array}$ & $\begin{array}{l}\mathrm{N}=134 \\
(\mathrm{M} 87, \mathrm{~F} 53)\end{array}$ & $\begin{array}{l}\text { PDT } \leq 1 \mathrm{hr}, 9 ; \\
\text { PDT }>1 \mathrm{hr}, 125 .\end{array}$ & $\begin{array}{l}\text { - Older age, female gender, } \\
\text { economic status, education } \\
\text { qualification, history of angina } \\
\text { were factors associated with }\end{array}$ \\
\hline
\end{tabular}




\begin{tabular}{|c|c|c|c|c|c|c|}
\hline & Chinese) & & & & & delay treatment in AMI patients. \\
\hline $\begin{array}{l}\text { Guixiang He, } \\
\text { Hui Zhang, } \\
\text { Ya Chen. }{ }^{[35]}\end{array}$ & $\begin{array}{l}\text { Chinese Journal } \\
\text { of } \\
\text { Gerontology } \\
\text { (in Chinese) }\end{array}$ & $\begin{array}{l}\text { Medical } \\
\text { record } \\
\text { and } \\
\text { patient } \\
\text { intervie } \\
\text { w via } \\
\text { telepho } \\
\text { ne }\end{array}$ & $\begin{array}{l}\text { Hunan } \\
\text { (souther } \\
\text { n China) }\end{array}$ & $\begin{array}{l}\mathrm{N}=293 \\
(\mathrm{M} 238, \mathrm{~F} 55)\end{array}$ & $\begin{array}{l}\text { PDT }<6 h r s, n=169 \\
\text { PDT } \geq 6 h r s, n=124\end{array}$ & $\begin{array}{l}\text { - Older age, atypical symptoms, } \\
\text { medical knowledge towards } \\
\text { angina, AMI or history of } \\
\text { angina, symptoms at night and } \\
\text { cost of treatment contributed to } \\
\text { delay. }\end{array}$ \\
\hline $\begin{array}{l}\text { Qiuhua Li, } \\
\text { Lei Li, } \\
\text { Yanrong Tie. } \\
\text { [37] }\end{array}$ & $\begin{array}{l}\text { Chinese Journal } \\
\text { of Misdiagnosis } \\
\text { (in Chinese) }\end{array}$ & $\begin{array}{l}\text { Questionn } \\
\text { aire } \\
\text { administra } \\
\text { tion } \\
\text { among } \\
\text { patients }\end{array}$ & $\begin{array}{l}\text { Hebei } \\
\text { (eastern } \\
\text { China) }\end{array}$ & $\begin{array}{l}\mathrm{N}=164 \\
(\mathrm{M} 123, \mathrm{~F} 41)\end{array}$ & $\begin{array}{l}\text { PDT >2hrs, n=99; } \\
\text { PDT>6hrs, n=41 }\end{array}$ & $\begin{array}{l}\text { - Attribution of symptoms to } \\
\text { cardiac causes was an } \\
\text { independant factor related to } \\
\text { early hospital arrival. } \\
\text { Progressive symptoms, onset at } \\
\text { night were factors associated } \\
\text { with prolonged pre-hospital } \\
\text { delay. The decision to seek } \\
\text { medical assistance was much } \\
\text { influenced by family members } \\
\text { for those onset at home. }\end{array}$ \\
\hline $\begin{array}{l}\mathrm{Li} \mathrm{Li} \text {, } \\
\text { Yizhi Wang, } \\
\text { Hongjun } \\
\text { Zhang. }^{[39]}\end{array}$ & $\begin{array}{l}\text { Chinese } \\
\text { Nursing } \\
\text { Research (in } \\
\text { Chinese) }\end{array}$ & $\begin{array}{l}\text { Questionn } \\
\text { aire } \\
\text { administra } \\
\text { tion } \\
\text { among } \\
\text { patients }\end{array}$ & Beijing & $\begin{array}{l}\mathrm{N}=164 \\
(\mathrm{M} 124, \mathrm{~F} 41)\end{array}$ & $\begin{array}{l}\text { PDT }>2 h r s, n=99 \\
\text { PDT }>6 h r s, n=41\end{array}$ & $\begin{array}{l}\text { - } \text { Correct attribution symptoms to } \\
\text { cardiac causes and severe } \\
\text { symptoms led to earlier } \\
\text { treatiment. The factors } \\
\text { associated with prolonged } \\
\text { pre-hospital delay ranged from }\end{array}$ \\
\hline
\end{tabular}




\begin{tabular}{|c|c|c|c|c|c|c|}
\hline & & & & & & $\begin{array}{l}\text { NSTEMI compared with } \\
\text { STEMI, cigarette smoking, to } \\
\text { onset at early dawn, and place of } \\
\text { onset of symptoms }\end{array}$ \\
\hline $\begin{array}{l}\text { Haiping } \\
\text { Wang, } \\
\text { Chun Zhang, } \\
\text { Qinghui Liu. } \\
\text { [40] }\end{array}$ & $\begin{array}{l}\text { Chinese Journal } \\
\text { of Misdiagnosis } \\
\text { (in Chinese) }\end{array}$ & $\begin{array}{l}\text { Questionn } \\
\text { aire } \\
\text { administra } \\
\text { tion } \\
\text { among } \\
\text { patients }\end{array}$ & $\begin{array}{l}\text { Shandon } \\
\text { g } \\
\text { (eastern } \\
\text { China) }\end{array}$ & $\begin{array}{l}\mathrm{N}=152 \\
(\mathrm{M} 110, \mathrm{~F} 42)\end{array}$ & $\begin{array}{l}\text { PDT } \leq 1 \mathrm{hr}, 20 ; \\
\text { PDT 1 6hrs, 45; } \\
\text { PDT >6hrs, 87. }\end{array}$ & $\begin{array}{l}\text { - Lack of awareness and } \\
\text { recognition of symptoms and a } \\
\text { failure to use the ambulance } \\
\text { system contributed to delay. } \\
\text { Self-administering medication } \\
\text { and awating effect, were found } \\
\text { factors impacting on pre-hospital } \\
\text { delay in AMI patients. }\end{array}$ \\
\hline $\begin{array}{l}\text { Shuili Li, } \\
\text { Shumei Yue. } \\
\text { [41] }\end{array}$ & $\begin{array}{l}\text { Chinese Journal } \\
\text { of Coal Industry } \\
\text { Medicine(in } \\
\text { Chinese) }\end{array}$ & $\begin{array}{l}\text { Questionn } \\
\text { aire } \\
\text { administra } \\
\text { tion } \\
\text { among } \\
\text { patients }\end{array}$ & $\begin{array}{l}\text { Anhui } \\
\text { (south } \\
\text { east } \\
\text { China) }\end{array}$ & $\begin{array}{l}\mathrm{N}=42 \\
(\mathrm{M} \mathrm{25}, \mathrm{F} 17)\end{array}$ & NR & $\begin{array}{l}\text { - A failure to recognise the correct } \\
\text { attribution of symptoms } \\
\text { contributed to PDT. Other } \\
\text { barriers of prompt treatment } \\
\text { decision were transportation and } \\
\text { medical expense. }\end{array}$ \\
\hline $\begin{array}{l}\text { Lufen Guo, } \\
\text { Yaguang } \\
\text { Peng, } \\
\text { Shujuan } \\
\text { Cheng, } \\
\text { Qingxiang } \\
\text { Li, } \\
\text { Dong Zhao, }\end{array}$ & $\begin{array}{l}\text { Beijing } \\
\text { Medicine (in } \\
\text { Chinese) }\end{array}$ & $\begin{array}{l}\text { Medical } \\
\text { record }\end{array}$ & Beijing & $\begin{array}{l}\mathrm{N}=807 \\
(\mathrm{M} 607, \mathrm{~F} 200)\end{array}$ & $\begin{array}{l}\text { PDT } \leq 2 h r s, 402 \\
\text { PDT } \geq 2 \text { hrs } 405\end{array}$ & $\begin{array}{l}\text { Older age, diabetes mellitus, } \\
\text { onset at night and attendance by } \\
\text { emergency medical services } \\
\text { were the associated factors with } \\
\text { PDT. }\end{array}$ \\
\hline
\end{tabular}




\begin{tabular}{|c|c|c|c|c|c|c|}
\hline $\begin{array}{l}\text { Zhaoguang, } \\
\text { Hong. }{ }^{[44]}\end{array}$ & & & & & & \\
\hline $\begin{array}{l}\text { Li Li, } \\
\text { Yizhi Wang, } \\
\text { Hongjun } \\
\text { Zhang. }{ }^{[45]}\end{array}$ & $\begin{array}{l}\text { Chinese } \\
\text { Nursing } \\
\text { Research (in } \\
\text { Chinese) }\end{array}$ & $\begin{array}{l}\text { In-depth } \\
\text { interview } \\
\text { with } \\
\text { patients }\end{array}$ & Beijing & $\begin{array}{l}\mathrm{N}=22 \\
(\mathrm{M} \mathrm{18}, \mathrm{F} 4)\end{array}$ & NR & $\begin{array}{l}\text { - The cognitive, psychological and } \\
\text { social factors were found to } \\
\text { influence treatment seeking } \\
\text { behaviors. Disease cognition } \\
\text { included symptom and } \\
\text { vulnerability assessment and } \\
\text { comparison with previous onset } \\
\text { symptoms. Psychological factor } \\
\text { included denial mechanism } \\
\text { when realizing suffering AMI, } \\
\text { and waiting for symptoms going } \\
\text { away and not disclosing } \\
\text { symptoms to others. Social } \\
\text { factors related to the time and } \\
\text { place of onset, people around } \\
\text { when attack occurred, } \\
\text { information resource and } \\
\text { socio-economic status. }\end{array}$ \\
\hline $\begin{array}{l}\text { Xiaodi Wu, } \\
\text { Yu Wang, } \\
\text { Fang Zhang, } \\
\text { Lu Wang. }{ }^{46]}\end{array}$ & $\begin{array}{l}\text { Chinese Critical } \\
\text { Care Medicine } \\
\text { (in Chinese) }\end{array}$ & $\begin{array}{l}\text { Questionn } \\
\text { aire } \\
\text { survey }\end{array}$ & $\begin{array}{l}\text { Tianjin } \\
\text { (eastern } \\
\text { China) }\end{array}$ & $\begin{array}{l}\mathrm{N}=108 \\
(\mathrm{M} 86, \mathrm{~F} 22)\end{array}$ & $\begin{array}{l}\text { PDT } \leq 2 \mathrm{hrs}, 40(37 \%) ; \\
\text { PDT2 4hrs,2 }(18.5 \%) ; \\
\text { PDT4 6hrs, } 6 \quad(5.6 \%) ; \\
\text { PDT>6hrs, } 42(38.9 \%) .\end{array}$ & $\begin{array}{l}\text { Severity of symptoms was found } \\
\text { closely related and AMI } \\
\text { symptom recognition was an } \\
\text { independent factor to long PDT. } \\
\text { - Gender and income were not } \\
\text { found to predict delay.. }\end{array}$ \\
\hline
\end{tabular}




\begin{tabular}{|c|c|c|c|c|c|c|}
\hline & & & & & & $\begin{array}{l}52 \text { out of } 108,(48.1 \%) \text { knew to } \\
\text { call120 for emergency } \\
\text { ambulance. Only 10, 9.3\% } \\
\text { arrived via ambulance. }\end{array}$ \\
\hline $\begin{array}{l}\text { Guixiang He, } \\
\text { Yaping } \\
\text { Chen, } \\
\text { XianghuaTan } \\
\text { g. }{ }^{47]}\end{array}$ & $\begin{array}{l}\text { Journal of } \\
\text { Nursing Science } \\
\text { (in Chinese) }\end{array}$ & $\begin{array}{l}\text { Medical } \\
\text { record \& } \\
\text { patient } \\
\text { interview } \\
\text { via } \\
\text { telephone }\end{array}$ & $\begin{array}{l}\text { Hunan } \\
\text { (souther } \\
\text { n China) }\end{array}$ & $\begin{array}{l}\mathrm{N}=205 \\
170, \mathrm{~F} 35)\end{array}$ & $\begin{array}{l}<60 \mathrm{ys}, \text { PDT11.38 } \pm 9.86 \mathrm{hrs} ; \\
\geq 60 \mathrm{ys}, \\
56.17+-52.20 \mathrm{hrs} .\end{array}$ & $\begin{array}{l}\text { - The pre-hospital delay was } \\
\text { longer in older patients. } \\
\text { Atypical symptoms, failure to } \\
\text { recognize significance, the cost } \\
\text { of hospitalization, } \\
\text { inconvenient transportation, no } \\
\text { bystanders at treatment onset, or } \\
\text { reluctance to trouble family } \\
\text { member if onset at night } \\
\text { contributed to delay } \\
\text { A lack of resources in hospitals } \\
\text { which not implement } \\
\text { thrombolytic treatment or PCI } \\
\text { led to delays in accessing } \\
\text { treatment }\end{array}$ \\
\hline Jun Qin. ${ }^{[48]}$ & $\begin{array}{l}\text { Medicine } \\
\text { Industry } \\
\text { Information(in } \\
\text { Chinese) }\end{array}$ & $\begin{array}{l}\text { Questionn } \\
\text { aire } \\
\text { survey }\end{array}$ & $\begin{array}{l}\text { Shanxi } \\
\text { (western } \\
\text { China) }\end{array}$ & $\begin{array}{l}\mathrm{N}=100 \\
(\mathrm{M} \mathrm{66,} \mathrm{F} \mathrm{34)}\end{array}$ & $\begin{array}{l}\text { PDT } \leq 6 \mathrm{hrs}, 21 ; \\
\text { PDT 6 24hrs, 52; } \\
\text { PDT >24hrs, 23. }\end{array}$ & $\begin{array}{l}\text { - A lack of knowledge regarding } \\
\text { AMI, the severity of symptoms, } \\
\text { lack of health insurance were } \\
\text { important factors influencing } \\
\text { delay treatment. }\end{array}$ \\
\hline $\begin{array}{l}\text { Ying } \mathrm{Wu}, \\
\text { Ying Zhang, }\end{array}$ & $\begin{array}{l}\text { Chinese } \\
\text { Medical Journal }\end{array}$ & $\begin{array}{l}\text { Questionn } \\
\text { aire }\end{array}$ & Beijing & $\begin{array}{l}\mathrm{N}=102 \\
(\mathrm{M} 78, \mathrm{~F} 24)\end{array}$ & $\begin{array}{l}\text { PDT } \leq 2 \mathrm{hrs}, 37 \\
\text { PDT }>2 \mathrm{hrs}, 65 .\end{array}$ & $\begin{array}{l}\text { Education level, atypical } \\
\text { presentation of AMI, and family }\end{array}$ \\
\hline
\end{tabular}




\begin{tabular}{|c|c|c|c|c|c|c|}
\hline $\begin{array}{l}\text { Yuqiu Li, } \\
\text { Baoli Hong, } \\
\text { Congxin } \\
\text { Huang. }{ }^{[49]}\end{array}$ & (in English) & $\begin{array}{l}\text { administra } \\
\text { tion }\end{array}$ & & & & $\begin{array}{l}\text { members at site were associated } \\
\text { with longer delay time in } \\
\text { seeking medical assistance. } \\
\text { - Intensity of chest pain was } \\
\text { inversely related to delay time. } \\
\text { Factors such as perception of a } \\
\text { good family relationship, correct } \\
\text { attribution of cardiac symptoms, } \\
\text { awareness of time-dependent } \\
\text { nature of reperfusion therapy, } \\
\text { use of emergency medical } \\
\text { service tended to timely access } \\
\text { to medical care. }\end{array}$ \\
\hline $\begin{array}{l}\text { Youhong } \\
\text { Xing, } \\
\text { Zhenhong } \\
\text { Fu, } \\
\text { Xiaoquan } \\
\text { Yang. }^{[52]}\end{array}$ & $\begin{array}{l}\text { Chinese } \\
\text { Nursing } \\
\text { Research (in } \\
\text { Chinese) }\end{array}$ & $\begin{array}{l}\text { Interview } \\
\text { with } \\
\text { patients/fa } \\
\text { mily } \\
\text { members }\end{array}$ & Beijing & $\begin{array}{l}\mathrm{N}=42 \\
(\mathrm{M} 35, \mathrm{F7})\end{array}$ & $\begin{array}{l}\text { Median of hospital visiting } \\
\text { time } 1.55 \mathrm{hrs} \text {; median of } \\
\text { emergency department } \\
\text { arrival time 4.55hrs. }\end{array}$ & $\begin{array}{l}\text { - Transportation was a significant } \\
\text { factor in predicting PDT. Other } \\
\text { factors influencing PDT were } \\
\text { income, medical expense, types } \\
\text { and attack times before. }\end{array}$ \\
\hline $\begin{array}{l}\text { Hongmei } \\
\text { Liu, } \\
\text { Xiaorong } \\
\text { Zhou, } \\
\text { Liang Luo. } \\
\text { [59] }\end{array}$ & $\begin{array}{l}\text { Chinese } \\
\text { Nursing } \\
\text { Research (in } \\
\text { Chinese) }\end{array}$ & $\begin{array}{l}\text { Questionn } \\
\text { aire } \\
\text { administra } \\
\text { tion }\end{array}$ & $\begin{array}{l}\text { Shanxi } \\
\text { (western } \\
\text { China) }\end{array}$ & $\begin{array}{l}\mathrm{N}=120 \\
(\mathrm{M} 85, \mathrm{~F} 35)\end{array}$ & $\begin{array}{l}\text { PDT ranged from } 1 \text { to } \\
\text { 17hrs, PDT } \leq 3 \mathrm{hrs,} 51 ; \\
\text { PDT }>3 \text { 3hrs, } 69 .\end{array}$ & $\begin{array}{l}\text { Factors related to delayed } \\
\text { hospital arrival includes older } \\
\text { age, symptoms at night, atypical } \\
\text { symptom, diabetic history, living } \\
\text { alone, low level services in local } \\
\text { hospital and access to } \\
\text { transportation. Female gender, }\end{array}$ \\
\hline
\end{tabular}




\begin{tabular}{|c|c|c|c|c|c|c|}
\hline & & & & & & $\begin{array}{l}\text { angina history, education level, } \\
\text { self-treatment were not found to } \\
\text { be statistically significant. }\end{array}$ \\
\hline $\begin{array}{l}\text { Wanqun Xu, } \\
\text { Xianfu Ma, } \\
\text { Liling Dai. } \\
\text { [54] }\end{array}$ & $\begin{array}{l}\text { Medical Journal } \\
\text { of Qilu } \\
\text { (in Chinese) }\end{array}$ & $\begin{array}{l}\text { Medical } \\
\text { records \& } \\
\text { patient } \\
\text { interview }\end{array}$ & $\begin{array}{l}\text { Shandon } \\
\text { g } \\
\text { (eastern } \\
\text { China) }\end{array}$ & $\begin{array}{l}\mathrm{N}=176, \\
(\mathrm{M} 91, \mathrm{~F} 85)\end{array}$ & $\begin{array}{l}\mathrm{PDT} \leq 6 \mathrm{hrs}, \mathrm{n}=94 ; \\
\mathrm{PDT}>6 \mathrm{hrs}, \mathrm{n}=82\end{array}$ & $\begin{array}{l}\text { - The factors associated with } \\
\text { pre-hospital delay for AMI were } \\
\text { older age, atypical symptoms, } \\
\text { female gender, health insurance } \\
\text { coverage, onset at night, history } \\
\text { of angina, and diabetic history. }\end{array}$ \\
\hline $\begin{array}{l}\text { Siqing Ding, } \\
\text { Xinlu Tao, } \\
\text { Meilian } \\
\text { Xiao. }^{[55]}\end{array}$ & $\begin{array}{l}\text { Journal of } \\
\text { Nursing Science } \\
\text { (in Chinese) }\end{array}$ & $\begin{array}{l}\text { Medical } \\
\text { record \& } \\
\text { patient } \\
\text { interview } \\
\text { via } \\
\text { telephone }\end{array}$ & $\begin{array}{l}\text { Hunan } \\
\text { (central } \\
\text { China) }\end{array}$ & $\begin{array}{l}\mathrm{N}=59 \\
(\mathrm{M} 44, \mathrm{~F} 15)\end{array}$ & $\begin{array}{l}\text { PDT ranged 1-72hrs, } \\
\text { PDT >6hrs } 34(57.6 \%) .\end{array}$ & $\begin{array}{l}\text { - Age, gender, education, CHD } \\
\text { history were factors associated } \\
\text { with PDT. } \\
\text { - } \\
\text { PDT was found in those of older } \\
\text { age, female gender and lower } \\
\text { than secondary school education. }\end{array}$ \\
\hline $\begin{array}{l}\text { Hua Zhang, } \\
\text { Hongwei } \\
\text { Zheng, } \\
\text { Pei Wang, } \\
\text { Hongyan } \\
\text { Zou, } \\
\text { Yueli Liang. } \\
\text { [56] }\end{array}$ & $\begin{array}{l}\text { Nursing Journal } \\
\text { of Chinese } \\
\text { People's } \\
\text { Liberation } \\
\text { Army(in } \\
\text { Chinese) }\end{array}$ & $\begin{array}{l}\text { Questionn } \\
\text { aire } \\
\text { survey }\end{array}$ & $\begin{array}{l}\text { Shangha } \\
\text { i } \\
\text { (souther } \\
\text { n China) }\end{array}$ & $\begin{array}{l}\mathrm{N}=186 \\
(\mathrm{M} 133, \mathrm{~F} 53)\end{array}$ & $\begin{array}{l}\text { PDT } \leq 1 \mathrm{hr}, 3 \%, \\
\text { PDT } \leq 6 \mathrm{hrs}, 37 \%, \\
\text { PDT6 12hrs, 48\%, } \\
\text { PDT }>12 \mathrm{hrs}, 12 \% .\end{array}$ & $\begin{array}{l}\text { Female gender, older age, } \\
\text { symptoms at night, living } \\
\text { alone, lower socioeconomic } \\
\text { status, and lack of health } \\
\text { education were common causes } \\
\text { of delay in ACS treatment. }\end{array}$ \\
\hline $\begin{array}{l}\text { Youshan } \\
\text { Gao, } \\
\text { Xuexian }\end{array}$ & $\begin{array}{l}\text { Chinese } \\
\text { Circulation } \\
\text { Journal(in }\end{array}$ & $\begin{array}{l}\text { Medical } \\
\text { record \& } \\
\text { patient }\end{array}$ & $\begin{array}{l}\text { Guangd } \\
\text { ong } \\
\text { (Souther }\end{array}$ & $\begin{array}{l}\mathrm{N}=414 \\
(\mathrm{M} 307, \mathrm{~F} 107)\end{array}$ & $\begin{array}{l}\text { PDT<=6hrs, n=221; } \\
\text { PDT >6hrs, n=193; }\end{array}$ & $\begin{array}{l}\text { - Older age, diabetic or angina } \\
\text { history and nocturnal onset were } \\
\text { independent factors associated }\end{array}$ \\
\hline
\end{tabular}




\begin{tabular}{|c|c|c|c|c|c|c|}
\hline $\begin{array}{l}\text { Qian, } \\
\text { Dabo Ma. }{ }^{[60]}\end{array}$ & Chinese) & interview & n China) & & & $\begin{array}{l}\text { with PDT for AMI. } \\
\text { - Female gender was not found an } \\
\text { independent factor in this study. }\end{array}$ \\
\hline $\begin{array}{l}\text { Jincheng } \\
\text { Guo, } \\
\text { Qi Hua, } \\
\text { Min Xu, } \\
\text { Yumei Wen, } \\
\text { Dongxia Liu, } \\
\text { Dongbao Li. } \\
\text { [61] }\end{array}$ & $\begin{array}{l}\text { Chinese Journal } \\
\text { of Critical Care } \\
\text { Medicine (in } \\
\text { Chinese) }\end{array}$ & $\begin{array}{l}\text { Questionn } \\
\text { aire } \\
\text { survey }\end{array}$ & Beijing & $\begin{array}{l}\mathrm{N}=412 \\
(\mathrm{M} 324, \mathrm{~F} 88)\end{array}$ & $\begin{array}{l}\text { PDT } \leq 2 h r s, n=167, \\
\text { PDT2 6hrs, } \quad n=142 ; \\
\text { PDT }>6 h r s, n=103 .\end{array}$ & $\begin{array}{l}\text { - Patient delay and diagnostic } \\
\text { dilemmas at the community } \\
\text { hospital were the main factors } \\
\text { responsible for PDT. } \\
\text { - Direct transfer to hospital, } \\
\text { sudden onset, progressive } \\
\text { symptoms, appropriate } \\
\text { recognition of symptoms, and } \\
\text { being worried about troubling } \\
\text { others were factors associated } \\
\text { with PDT } \\
\text { Older age, female gender, high } \\
\text { risk factors such as hypertension, } \\
\text { diabetes, hyperlipidemia, and } \\
\text { background of symptom onset, } \\
\text { were not found associated with } \\
\text { PDT. }\end{array}$ \\
\hline $\begin{array}{l}\text { Jincheng } \\
\text { Guo, } \\
\text { Qi Hua, } \\
\text { Dongxia Liu, } \\
\text { Hailing } \\
\text { Chen, }\end{array}$ & $\begin{array}{l}\text { Chinese Journal } \\
\text { of General } \\
\text { Practitioner (in } \\
\text { Chinese) }\end{array}$ & $\begin{array}{l}\text { Questionn } \\
\text { aire } \\
\text { survey }\end{array}$ & Beijing & $\begin{array}{l}\mathrm{N}=329 \\
(\mathrm{M} 258, \mathrm{~F} 71)\end{array}$ & $\begin{array}{lr}\text { PDT } \leq 1 \mathrm{hr}, \quad 156 \quad(47.4 \%) ; \\
\text { PDT } \leq 2 \mathrm{hrs}, & 120(65 \%) ; \\
\text { PDT6 72hrs, } 274(83.3 \%) .\end{array}$ & $\begin{array}{l}\text { Taking analgesia, waiting for } \\
\text { symptoms going away, } \\
\text { reluctance to bother others, } \\
\text { angina before infarction, age } \\
\geq 65 y \text { and gradual onset of } \\
\text { symptoms were factors related to }\end{array}$ \\
\hline
\end{tabular}




\begin{tabular}{|c|c|c|c|c|c|c|}
\hline $\begin{array}{l}\text { Ji Xu, } \\
\text { Yumei Wen, } \\
\text { Dongbao Li. } \\
\text { [62] }\end{array}$ & & & & & & $\begin{array}{l}\text { longer pre-hospital delay. } \\
\text { - Having others present at } \\
\text { symptom onset, the intensity of } \\
\text { pain and, attention to symptoms } \\
\text { were factors associated with } \\
\text { shorter PDT. }\end{array}$ \\
\hline $\begin{array}{l}\text { Jingpu Shi, } \\
\text { Bingshun } \\
\text { Wang, } \\
\text { Tianjue } \\
\text { Wang, } \\
\text { Baoxia Guo, } \\
\text { Meng Wei, } \\
\text { Zhaojin Liu, } \\
\text { Lihua Song. } \\
\text { [63] }\end{array}$ & $\begin{array}{l}\text { Chinese Journal } \\
\text { of Public Health } \\
\text { (in Chinese) }\end{array}$ & $\begin{array}{l}\text { Questionn } \\
\text { aire } \\
\text { survey }\end{array}$ & $\begin{array}{l}\text { Liaonin } \\
\text { g } \\
\text { (norther } \\
\text { n China) }\end{array}$ & $\begin{array}{l}\mathrm{N}=100 \\
\text { (gender NR) }\end{array}$ & $\begin{array}{l}\mathrm{PDT} \leq 1 \mathrm{hr}, \mathrm{n}=100 \\
\mathrm{PDT}>1 \mathrm{hr}, \mathrm{n}=100\end{array}$ & $\begin{array}{l}\text { - Lower level of education, low } \\
\text { intensity of hospital services, } \\
\text { and history of being treated in } \\
\text { intensive care unit or rescued } \\
\text { before, were found related } \\
\text { factors among those patients } \\
\text { whose PDT }>1 \mathrm{hrs.}\end{array}$ \\
\hline $\begin{array}{l}\text { Dayi Hu, } \\
\text { Zhimin Xu, } \\
\text { Liang Cui, } \\
\text { Xiangmin } \\
\text { Lin, } \\
\text { Hong Wang, } \\
\text { Mulei Chen, } \\
\text { Jianzhang } \\
\text { Liu. }^{\text {[64] }}\end{array}$ & $\begin{array}{l}\text { Journal of } \\
\text { Emergency } \\
\text { Medicine (in } \\
\text { Chinese) }\end{array}$ & $\begin{array}{l}\text { Medical } \\
\text { record }\end{array}$ & Beijing & $\begin{array}{l}\mathrm{N}=111 \\
(\mathrm{M} 83, \mathrm{~F} 28)\end{array}$ & $\begin{array}{lcc}\text { PDT } & 144.2+\_119.2 & \text { mins; } \\
\text { PDT } & >150 \text { mins, } \quad n=38 \\
(34 \%) . & \end{array}$ & $\begin{array}{l}\text { - Lack of symptom recognition, } \\
\text { lack of access to transportation, } \\
\text { being alone at symptom onset, } \\
\text { delays in community hospitals } \\
\text { and atypical symptoms } \\
\text { contributed to PDT. }\end{array}$ \\
\hline
\end{tabular}




\begin{tabular}{|c|c|c|c|c|c|c|}
\hline $\begin{array}{l}\text { Junjie Gong, } \\
\text { Pengbo } \\
\text { Wang, } \\
\text { Junbo Wang, } \\
\text { Ruqin Shan, } \\
\text { Changqing } \\
\text { Teng. }{ }^{\text {[71] }} \\
\end{array}$ & $\begin{array}{l}\text { Clinical Focus } \\
\text { (in Chinese) }\end{array}$ & $\begin{array}{l}\text { Patient } \\
\text { interview }\end{array}$ & $\begin{array}{l}\text { Shandon } \\
\text { g } \\
\text { (eastern } \\
\text { China) }\end{array}$ & $\begin{array}{l}\mathrm{N}=414 \\
(\mathrm{M} 307, \mathrm{~F} 107)\end{array}$ & $\begin{array}{l}\text { PDT } \leq 6 h r s, n=221 ; \\
\text { PDT }>6 \text { hrs, } n=193\end{array}$ & $\begin{array}{l}\text { - Older age , diabetic or angina } \\
\text { history and time of symptom onset } \\
\text { were the independent factors } \\
\text { associated with PDT in AMI } \\
\text { patients. }\end{array}$ \\
\hline $\begin{array}{l}\text { Ning Li, } \\
\text { Shaoru } \\
\text { Zhang, } \\
\text { Yinping } \\
\text { Zhang. }{ }^{[72]}\end{array}$ & $\begin{array}{l}\text { Chinese } \\
\text { Nursing } \\
\text { Research (in } \\
\text { Chinese) }\end{array}$ & $\begin{array}{l}\text { Questionn } \\
\text { aire } \\
\text { survey }\end{array}$ & $\begin{array}{l}\text { Shanxi } \\
\text { (western } \\
\text { China) }\end{array}$ & $\begin{array}{l}\mathrm{N}=173 \\
(\mathrm{M} 127, \mathrm{~F} 46)\end{array}$ & NR & $\begin{array}{l}\text { Gender, age , educational level, } \\
\text { personality and concern } \\
\text { regarding the cost of treatment } \\
\text { contributed to coping styles. }\end{array}$ \\
\hline $\begin{array}{l}\text { Shujuan } \\
\text { Cheng, } \\
\text { Lufen Guo, } \\
\text { Juyuan Liu, } \\
\text { Xiaoling } \\
\text { Zhu, } \\
\text { Hongbing } \\
\text { Yan. }{ }^{\text {[3] }}\end{array}$ & $\begin{array}{l}\text { Journal of } \\
\text { Geriatric } \\
\text { Cardiology (in } \\
\text { English) }\end{array}$ & $\begin{array}{l}\text { Medical } \\
\text { record \& } \\
\text { patient } \\
\text { interview }\end{array}$ & Beijing & $\begin{array}{l}\mathrm{N}=807 \\
(\mathrm{M} 406, \mathrm{~F} 401)\end{array}$ & $\begin{array}{l}\text { Median PDT } 130 \text { mins; } \\
\text { PDT } \leq 2 \mathrm{hrs,} \mathrm{n}=402 \\
\text { PDT }>2 \mathrm{hrs}, \mathrm{n}=405\end{array}$ & $\begin{array}{l}\text { - Older age, history of diabetes, } \\
\text { onset of symptoms at night } \\
\text { contributed to PDT. While use of } \\
\text { emergency medical service } \\
\text { reduced PDT than other means } \\
\text { of transportation. } \\
\text { - Interventions to reduce PDT } \\
\text { should focus on the awareness of } \\
\text { the risk and medical help } \\
\text { seeking behavior of patients. }\end{array}$ \\
\hline
\end{tabular}


$\mathrm{M}=$ male,

$\mathrm{F}=$ female,

ys=years

hrs=hours

mins $=$ minutes

$\mathrm{UAP}=$ unstable angina pain

$\mathrm{AMI}=$ acute myocardial infarction

$\mathrm{NR}=$ not reported 